\title{
Geographic Information Systems (GIS) Application for Tsunami Inundation Modeling in Bantul Regency, Yogyakarta
}

\author{
Putu Perdana Kusuma Wiguna \\ Teknik Planologi, Fakultas Teknik Universitas Hindu Indonesia \\ Denpasar, Indonesia \\ putu.perdana@gmail.com
}

\begin{abstract}
Tsunami(s) are natural disasters generated by abrupt, large disturbance of ocean bottom such as earthquakes, volcanic eruptions, landslides, or meteor impacts which creates high ocean waves. Tsunami events has devastating effects, especially to population which highly exposed by tsunami. This research conducted in Bantul Regency, Yogyakarta Province, Indonesia. The geomorphologic conditions and location of Bantul Regency makes Bantul becomes vulnerable to tsunami hazard triggered by earthquakes originated from subduction of the Indian-Australian Plate and Eurasian Plate in the Indian Ocean.
\end{abstract}

This research applied Geographic Information Systems (GIS) modeling methods based on Digital Elevation Data (DEM) and tsunami inundation scenario of 5 meter, 7.5 meter and 10 meter. The model is built using 'neighbourhood operations' and 'iteration' processes using ILWIS software. The results of this research are tsunami inundation map in Bantul Regency, area of landuse exposed by tsunami events, and number of population impactedby tsunami inundation in Bantul Regency.

The total of inundated area in the 5 meter inundation model is $38.13 \mathrm{~km}^{2}$, followed by $42.93 \mathrm{~km}^{2}$ for the 7.5 meter model and $76.02 \mathrm{~km}^{2}$ for the 10 meter model. Majority of landuse impacted by tsunami are settlements and ricefields. 5 meter inundation model reach 2,328 meter to land from 0 meter start, the 7.5 meter model reach 4,141 meter and 10 meter model reach 4,844 meter. There are 5 Sub-districts that really impacted by tsunami, i.e. Kretek, Sanden, Srandakan, Bambanglipuro and Pundong. Srandakan, Sanden and Kretek.

Total of population impacted by tsunami reached 60572 in the 10 meter inundation model. Meanwhile, total of 8165 residents impacted from tsunami with 5 meter inundation model and 43088 residents from 10 meter model. The highest number of population impacted by tsunami is in Sanden, with total 25528 residents.

Keywords-GIS, tsunami inundation, modeling, landuse, population

\section{INTRODUCTION}

Tsunami(s) are series of ocean waves generated by abrupt, large disturbance of ocean bottom such as earthquakes, volcanic eruptions, landslides, slumps, or meteor impacts (Bernards, 1999). Although wave height is relatively small in open seas, when the tsunami hits the coastline, it may rise to several meters and can cause loss of lives and property damage when it comes to shores (Yalciner et al, in Amin, 2006). In shores, tsunami waves may reach $20 \mathrm{~m}$ in heights and spread as far as $5 \mathrm{~km}$ depends on the topographic and the wave's energy. Tsunami events has devastating effects, it may effects population/ residents, properties, infrastructures and major economic collapse.

Population is considered one of the most vulnerable element that exposed by tsunami. Many research has been conducted to minimize the lost of population and lowering the vulnerability. Previous tsunami events, such as happened in Aceh in 2004, has thought us that lack of preparedness has cause the lost of many lives.

Previous events thought us that tsunami has destructive power to environment and people who lives in the tsunami prone areas. Mitigations and preparedness are important not only to cities which located in tsunami disaster areas, also for cities with potential events of tsunami. It can be derived in several ways, mapping the potential tsunami hazard area is one basic for make mitigation planning.

To map the spatial distributions of tsunami events and to knowing its impact on elements at risk, can be examined by the use of Geographic Information Systems (GIS) and Remote Sensing.Research using Remote Sensing and GIS data provide valuable information for further detailedassessment as pre-tsunami preparedness and the effect of tsunami. 
In order to understand the possible effects of tsunami in mainland, GIS modeling method can be conducted to create a map of tsunami inundation areas based on topographical conditions of the land surface, and scenarios of tsunami inundation.Modeling method in this research is using 'neighbourhood operation' and 'iteration' to count the spread of tsunami water in land. As a plan for mitigation, number of population and area of landuse exposed by tsunami also calculated using recent population data and landuse map.

Bantul Regency is one of five Regencies in Yogyakarta Province. It is located in the southern part of Yogyakarta. Bantul is bordered by Yogyakarta City to the north, the Regencies of Kulon Progo and Sleman to the west, Gunung Kidul Regency to the east and the Indian Ocean to the south.Bantul Regency has area of $508.85 \mathrm{Km}^{2}$ or $15.90 \%$ from total area of Yogyakarta Province. (Pemkab Bantul, 2012).

Middle part of Bantul Regency is topographically flat until undulating, which is very fertile for ricefields. The east and west side of the regency are hilly/ mountainous due to the geomorphological faults that creates Graben Bantul. A graben is a down-dropped block of the earth's crust resulting from extension, or pulling, of the crust (United States Geological Survey, 2012 ${ }^{\mathrm{a}}$ ). Graben represents a geomorphologic phenomenon which creates conditions in which the middle part of the area is lower than the flanks that called Horst.

The geomorphologic conditions and location of Bantul Regency makes Bantul becomes vulnerable to tsunami hazard which triggered by earthquakes. The potential earthquake is originated from subduction of the Indian-Australian Plate and Eurasian Plate in the Indian Ocean (United States Geological Survey, 2012b). Sudden movements in the fault lines of the subduction areas produce tectonic earthquake and produce aftershock hazard which is tsunami. Figure 1 show the map of Bantul Regency, Yogyakarta Province, Indonesia.

The main goal of this research is to create map of tsunami inundation area by using model of inundation height. The result will become one of preparation to face tsunami hazard. The objectives of this research are:

To map the tsunami inundation in Bantul Regency, using GIS application

To understand the number of landuse exposed to tsunami events,

To understand the number of population impacted by tsunami events in Bantul Regency.

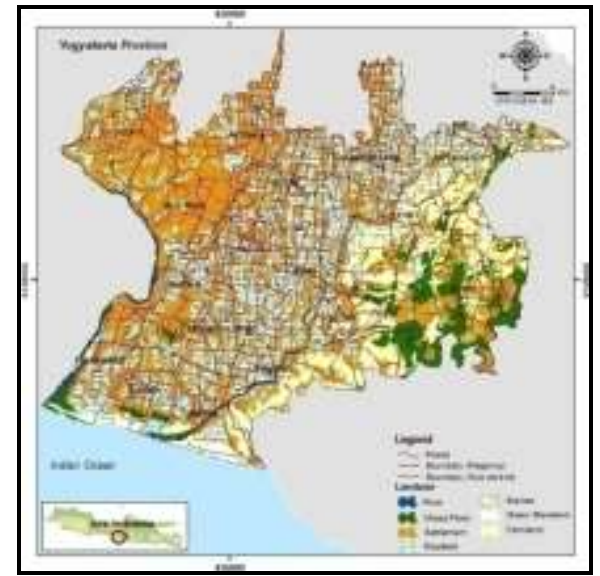

Figure 1. Landuse Map of Bantul Regency

(Source: RBI Maps of Bantul Regency scale 1: 25,000)

\section{RESEARCH METODHODOLOGY}

The research area is in Bantul Regency, Yogyakarta Province, Indonesia. Means of Geographic Information Systems (GIS) applied in the research are modeling methods based on Digital Elevation Data (DEM) and tsunami inundation scenario. The model will calculated using 'neighbourhood operations' and 'iteration' processes.

A. Data

Data in this research are mainly spatial data of Bantul Regency which mentioned as follows;

1. Contour map, with contour index of $12.5 \mathrm{~m}$

2. Landuse map, scale of 1:25,000

3. Population data, 2012

4. Tsunami inundation scenarios

All data will be processed using ILWIS 3.4 software and ArcGIS version 9.3.

\section{B. Methods}

\section{Tsunami Modeling}

Tsunami modeling and mapping in this research are based on Digital Elevation Data (DEM) which derived from contour data processed using ILWIS Software. In ILWIS, DEM is obtained by interpolation of segments, by an interpolation of points, or by an interpolation of a raster map which contains rasterized value segments and points. DEM is the basic of tsunami inundation modeling in this research. Figure 2 shows the ILWIS's homepage. ILWIS is an abbreviation of Integrated Land Water Information Systems, software developed by Faculty of Geoinformation Science and Earth Observation (ITC), University of Twente. 


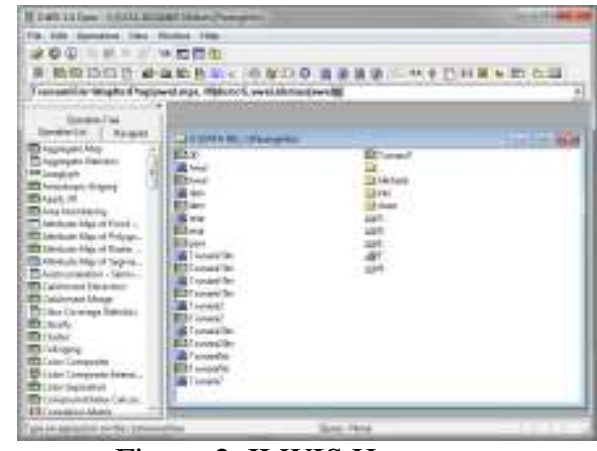

Figure 2. ILWIS Homepage (source: ILWIS)

The tsunami modeling in this research is calculated using neighbourhood operations. Neighbourhood operations are a special spatial analysis used in ILWIS. They are calculations on pixels in which the outcome depends on the neighbouring pixels. Neighbourhood operations may be performed on selected pixels as well as on whole map. Just as in filtering procedures, neighbourhood operations make use of a filter. This window of 3 by 3 cells is moved over the raster map. Each cell of the output map is calculated according to the specified neighbourhood expression. The cell numbers in the moving window are coded as shown in Figure 3.

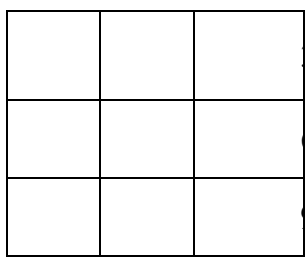

Figure 3. Cell Numbers intheMoving Window

This means that the left neighbour of the central pixel is coded number 4 and the lower right pixel number 9. By definition the central pixel itself is included and has number 5 . The result of the calculation is stored in the central pixel.

Iteration calculation is used to recognize the neighbouring pixels in raster format. Iteration is a special type of calculation. It is a successive repetition of a mathematical operation, using the result of one calculation as input for the next one. The calculation stops when the difference of the output compared to the input is negligible or if the number of iterations is reached as previously defined. Iterations are often used in combination with neighbourhood operations. Such an application might be for instance the selection of an item or area which fits a certain condition, starting from one pixel. Basic of iteration expressions are shown as follows,

Syntax:

MAPITER(StartMap, IterExpr)

MAPITER(StartMap, Iterexpr, Nr of Iterations)

StartMapis a raster data contain line which indicate 0 meter height above sea level. This line is a starting point to start the iteration process. Meanwhile IterExpris thescriptin ILWIS to start iteration process with propagation. Ilustration of neighbourhood operation and iteration processes to produce inundation map is presented in Figure 4.

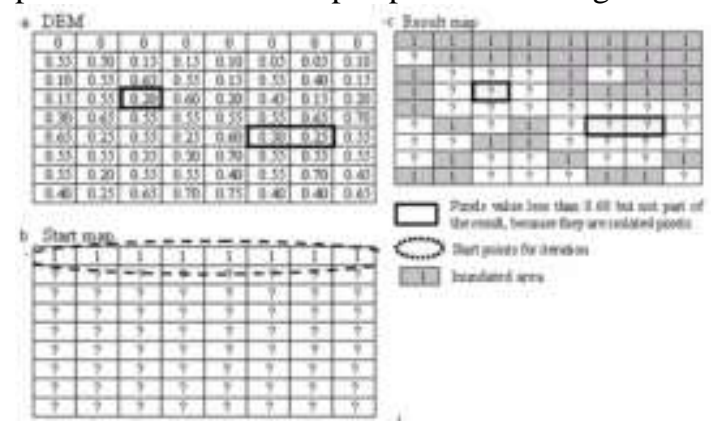

Figure 4. Neighbourhood Operation dan Iteration Illustration (Marfai, 2009)

The nearest neighbouring pixels will identified as tsunami inundation prone area. As example, for 1 meter tsunami height, iteration process for determine the inundation area will stop at pixel with value 1 meter from above sea level $(0$ meter)

The tsunami inundation scenarios are based on worst case scenario that could possibly happen. The scenarios are 5 meter, 7.5 meter and 10 meter.

\section{Total Landuse Impacted by Tsunami}

The area of landuse impacted by tsunami is calculated using overlay analysis in ArcGIS 9.3. The inundated landuse will be intersected per inundation scenarios to calculate the area in $\mathrm{Km}^{2}$ and percent $(\%)$

\section{Number of Population Exposed by Tsunami}

The number of population exposed by tsunami is determined using population data per Sub-district (Kecamatan). The population data will gives explanations about how many lives are exposed by tsunami in Bantul Regency per Subdistrict per inundated area. The process to classify the population data involved Overlay Analysis using ArcGIS 9.3. The calculation of population number per inundated area per sub-district is based on area settlement as explained in expression as follows; 
Number OfPopwlation $=\frac{\text { Impacted Settiement }}{\text { Total Area of Sentement }} \times$ TotaiPopulation (3)

This expression works with assumption that the population is evenly spread in the settlements.

\section{RESULTS AND DISCUSSIONS}

1. Tsunami Modeling and Impact to Population

DEM data is very essentials in this research. Figure 5 presents the Digital Elevation Model and 3D model of the study area. The mountainous area at the east side makes it become safe area from inundation. Meanwhile the red circle indicates undulating/ hilly area in the middle which makes the iteration processes to stop.

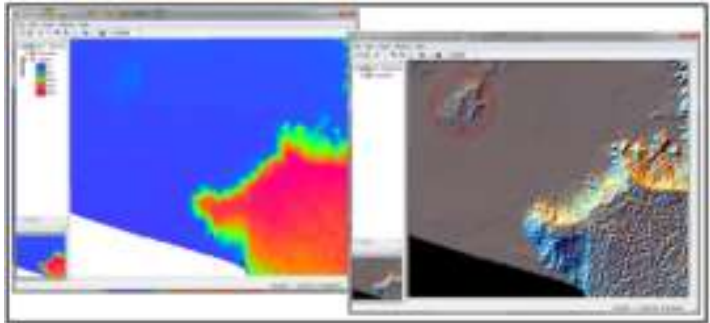

Figure 5. DEM and 3D Model of the Research Area

(Source: Contour Map)

The result of tsunami modeling is presented in Figure 6. The result indicates that topographic condition really affects the spreading pattern of. The 5 meter inundation model reach 2,328 meter to land from zero meter start, the 7.5 meter model reach 4,141 meter and 10 meter model reach 4,844 meter. The different length of inundation shows the topographical barrier in the north side. The 7.5 inundation model almost reach 2 times longer than 5 meter model but the 10 meter model only 700 meter longer than 7.5 meter model. In the north side there is Merapi volcano which makes the topography become steeper as it face north. The little hills in the middle of the area makes it become un-inundated.

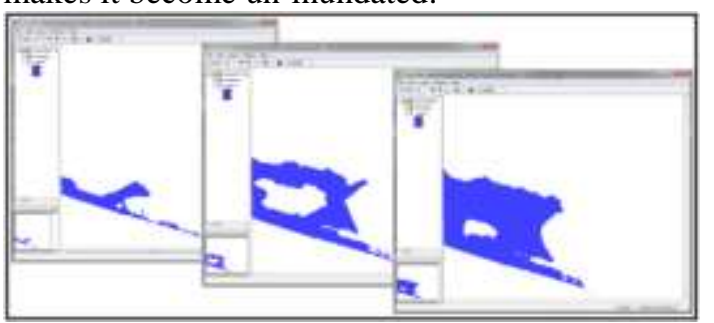

Figure 6. Results of the Inundation Model (Source: ILWIS, DEM Analysis)

Based on the inundation results, the final map of inundated areas in Bantul Regency is presented in
Figure 7. The maps shows that there are 5 Subdistricts that really impacted by tsunami, i.e. Kretek, Sanden, Srandakan, Bambanglipuro and Pundong. These 5 sub-districts have direct boundaries to Indian Ocean, that makes the most impacted areas will be located in these 5 Subdistricts.

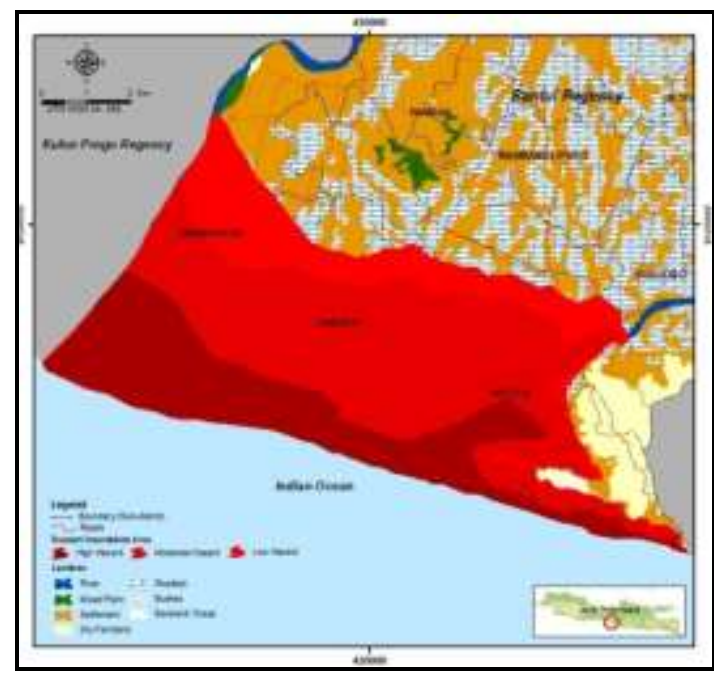

Figure 7. Result of the Inundation Map

(Source: Landuse Map, DEM Analysis)

Tsunami inundation creates impact on the landuse of Bantul Regency. The total of inundated area in the 5 meter inundation model is $38.13 \mathrm{~km}^{2}$, followed by $42.93 \mathrm{~km}^{2}$ for the 7.5 meter model and $76.02 \mathrm{~km}^{2}$ for the 10 meter model. Majority of landuse impacted by tsunami are settlements and ricefields. $66.27 \%$ settlements are impacted by 5 meter tsunami model, $32.59 \%$ in 7.5 meter model and $25.56 \%$ of the 10 meter model. It is indicted that the coastal area of Bantul Regency has more impact to tsunami than the northern part. The total landuse impacted by tsunami is presented in Table 1.

Table 1. Area of Landuse Impacted By Tsunami

\begin{tabular}{|c|c|c|c|c|c|c|}
\hline \multirow{3}{*}{ Landuse } & \multicolumn{6}{|c|}{ Inundated Area } \\
\hline & \multicolumn{2}{|c|}{$5 \mathrm{~m}$ model } & \multicolumn{2}{|c|}{$7.3 \mathrm{mrmodel}$} & \multicolumn{2}{|c|}{10 in model } \\
\hline & $\overline{n m r^{2}}$ & 2 & $5 m r^{2}$ & $\because$ & $\kappa m^{2}$ & $\therefore$ \\
\hline Settlement & 25.27 & 66.27 & 13.99 & 32.59 & 19.59 & 25.56 \\
\hline Ricefield & 4.11 & 10.78 & 1737 & 40.47 & 22.16 & 28.92 \\
\hline Bareland/Grass & 2.55 & 6.68 & 2.45 & 5.71 & 25.33 & 33.06 \\
\hline Dry Farniand & 2.77 & 7.26 & 5.13 & 11.95 & 5.53 & 7.22 \\
\hline Mix Plantation & 3.43 & 8.99 & 3.98 & 9.27 & 4.01 & 5.23 \\
\hline Total & 38.13 & 100 & 42.93 & 100 & 76,02 & 100 \\
\hline
\end{tabular}

(Source: Landuse Map, Tsunami Inundation Map)

Settlements are the most exposed to tsunami inundation. The number of population in the inundated area is calculated with assumption that the population is evenly spread in the settlements. 
The focus of analysis is the 5 impacted Subdistricts. The densely populated areas are Bambanglipuro and Pundong, with more than 30000 residents. The total population per Subdistricts is presented in Table 2. Using expression (3), the number of population impacted by tsunami is presented in Table 3 .

Total number of population impacted by tsunami reached 60572 in the 10 meter inundation model. There is high leap of impacted residents from 5 meter inundation model to 7.5 meter inundation model, which is from 8165 to 43088 . The smallest impacted areas are Bambanglipuro and Pundong. Bambanglipuro only have 5 residents affected by tsunami in 10 meter model, meanwhile Pundong has only 9 residents impacted in 7.5 meter model and 145 residents in the 10 meter model. The highest impacted area is Sanden, with total 25528 residents from 10 meter inundation model.

Table 2. Number of Population (per Dec 6, 2012)

\begin{tabular}{|l|r|}
\hline Sub-district & Population \\
\hline Srandakan & 28367 \\
\hline Sanden & 29449 \\
\hline Kretek & 28648 \\
\hline Pundong & 31447 \\
\hline Bambanglipuro & 38223 \\
\hline
\end{tabular}

(Source: Komisi Pemilihan Umum, 2012)

Table 3. Number of Population Impacted By Tsunami

\begin{tabular}{|l|c|r|r|}
\hline \multirow{2}{*}{ Sub-district } & \multicolumn{3}{|c|}{ Number of Population } \\
\cline { 2 - 4 } & $5 \mathrm{~m}$ model & $\mathbf{7 , 5} \mathrm{m}$ model & $10 \mathrm{~m}$ model \\
\hline Bambangdipuro & - & - & 5 \\
\hline Pundong & - & 9 & 145 \\
\hline Kretek & 2231 & 16755 & 22073 \\
\hline Sanden & 1432 & 18898 & 25528 \\
\hline Srandakan & 4502 & 7425 & 12821 \\
\hline Total & 8165 & 43088 & 60572 \\
\hline
\end{tabular}

(Source: Komisi Pemilihan Umum, 2012, Landuse Map)

\section{Building Public Awareness}

Howes (2006), writes that public awareness of hazard can be improved through communication activities through television, radio and internet campaigns; via the distribution of information leaflets, brochures, posters and videos; and information sessions at public information meetings. Such activities are important since Schütz and Wiedemann (2000) found that providing risk information to the public resulted in an increase of public trust in risk mitigation and planning competence. Schütz and Wiedemann
(2000) suggest that risk information should be provided to a community within a timeframe of less than once every three years to ensure risk knowledge does not decrease. However, a study conducted by Johnston et al., (2005) on tsunami preparedness in coastal Washington revealed that despite distributing tsunami information through several media, erecting tsunami warning and evacuation signs, and providing maps and public displays illustrating tsunami inundation zones, levels of preparedness were still rather low. Therefore, the challenges for achieving successful community based tsunami risk mitigation are numerous and complex.

\section{CONCLUSSIONS AND RECOMENDATIONS}

\section{Conclusions}

The inundation models conclude difference in area of inundation. 5 meter inundation model reach 2,328 meter to land from 0 meter start, the 7.5 meter model reach 4,141 meter and 10 meter model reach 4,844 meter. There are 5 Sub-districts that really impacted by tsunami, i.e. Kretek, Sanden, Srandakan, Bambanglipuro and Pundong. Srandakan, Sanden and Kretek.

The total of inundated area in the 5 meter inundation model is $38.13 \mathrm{~km}^{2}$, followed by 42.93 $\mathrm{km}^{2}$ for the 7.5 meter model and $76.02 \mathrm{~km}^{2}$ for the 10 meter model. Majority of landuse impacted by tsunami are settlement and ricefield.

Total of population impacted by tsunami reached 60572 in the 10 meter inundation model. Meanwhile, total of 8165 residents impacted from tsunami with 5 meter inundation model and 43088 residents from 10 meter model. The highest impacted area is Sanden, with total 25528 residents

\section{Recommendations}

Disastrous events like tsunamis cannot be totally eliminated but however preparedness is always important. Using the help of GIS technologies, the preparedness to tsunami events can be possible. GIS helps to create inundation map for the study by the result of a tsunami modeling. It is a basic map for areas with potentials of tsunamis. It is a base for evacuation efforts in the case of disasters which should be evaluated for the mitigation and pre-disaster efforts. By using GIS, the risk maps and evacuation plans can be arranged for disaster risk reduction efforts also in the emergency action plans. 


\section{REFERENCES}

Budiarjo, A. 2006. Evacuation Shelter Building Planning for Tsunami Prone Area; a Case Study of Meulaboh City, Indonesia. Thesis. University of Twente. Unpublished

Bernard, E. 1999. Tsunami. In: Natural Disaster Management, a presentation to commemorate the International Decade for Natural Disaster Reduction (IDNR) 1999-2000, J. Ingleton, Eds. Tudor Rose Holding Limited, Leicester, pp. 58-60.

Howes, B, D. Howes. 2006. Tsunami risk mitigation and theissue of public awareness. The Australian Journal of Emergency Management, Vol. 21 No. 4, November 2006
Pengolahan
Data
Telematika Pemerintah Kabupaten Bantul. 2012. Data Pokok Kabupaten Bantul. [Online]. Available: http://bantulkab.go.id/datapokok/. [May 25, 2013]
Komisi Pemilihan Umum. 2013. DataAgregat Kependudukan Per Kecamatan [Online].Available:www.kpu.go.id/dmdocuments/(8 1.2013)\%20DIY.pdf] .May 27, 2013[.

Marfai, M. A. 2009. ILWIS Exercise Module: Coastal Flood Assessment by Means of GIS Technology. Yogyakarta: Fakultas Geografi Universitas Gadjah Mada.

Schütz, H. and Wiedemann, P.M. 2000. Hazardous Incident Information for the Public: Is it Useful? The Australasian Journal of Disaster and Trauma Studies. ISSN: 1174-4707. Volume: 2000-2.

United States Geological Survey (a). 2012. Earthquake Glossary. [Online].Available: earthquake.usgs.gov/learn/dictionary. [May 27, 2013]

United States Geological Survey ${ }^{(b)}$. 2012. Tsunamis and Earthquakes. [Online].Available: http://walrus.wr.usgs.gov/tsunami/CIHH.html. [May 27, 2013]. 